\title{
Standardization of Milk Using Cold Ultrafiltration Retentates for the Manufacture of Parmesan Cheese
}

\author{
S. Govindasamy-Lucey, ${ }^{1}$ J. J. Jaeggi, ${ }^{1}$ A. L. Bostley, ${ }^{1}$ \\ M. E. Johnson, ${ }^{1}$ and J. A. Lucey ${ }^{2}$ \\ ${ }^{1}$ Wisconsin Center for Dairy Research, \\ ${ }^{2}$ Department of Food Science, University of Wisconsin-Madison, \\ Madison 53706
}

\section{ABSTRACT}

The effects of using cold ultrafiltered (UF) retentates (both whole and skim milk) on the coagulation, yield, composition, and ripening of Parmesan cheese were investigated. Milks for cheese making were made by blending cold UF retentates with partially skimmed milk to obtain blends with $14.2 \%$ solids and a casein:fat ratio of 1.1. Cutting times, as selected by the cheesemaker, were $\sim 15$ and $\sim 20$ min for experimental and control milks, respectively. Storage modulus values at cutting were similar, but yield stress values were significantly higher in UF retentate standardized milks. Cheese yields were significantly higher in UF retentate standardized milks $(\sim 12 \%)$ compared with control milk (cream removed) ( 7 to $8 \%$ ). Significantly higher protein recoveries were obtained in cheeses manufactured using cold UF retentates. There were no differences in the $\mathrm{pH}$ and moisture contents of the cheeses prior to brining, and there was no residual lactose or galactose left in the cheeses. Using UF retentates resulted in a significant reduction in whey volume as well as a higher proportion of protein in the solids of the whey. Proteolysis, free fatty acids, and sensory properties of the cheeses were similar. The use of milk concentrated by cold UF is a promising way of improving the yield of Parmesan cheese without compromising cheese quality. The question remaining to be answered by the cheesemaker is whether it is economical to do so.

(Key words: Parmesan cheese, ultrafiltration, cheese yield, rennet coagulation)

Abbreviation key: $\mathbf{G}^{\prime}=$ storage modulus, LCF-UF = low concentration factor UF, SUF = skim milk, WUF = whole milk UF.

Received February 20, 2004.

Accepted May 31, 2004.

Corresponding author: S. Govindasamy-Lucey; e-mail: rani@cdr. wisc.edu.

\section{INTRODUCTION}

Most of the recent growth in the US milk production has been in the West or Southwest. Milk production in Wisconsin has remained stable over the past few years, while demand by cheese manufacturers for milk continues to increase. As a result, cheese plants in the Upper Midwest (Minnesota, Wisconsin) are often short of sufficient milk for cheese making and use NDM for standardization and to help increase cheese yield. In 1996, the FDA approved the use of cold $\left(<7^{\circ} \mathrm{C}\right) \mathrm{UF}$ of milk for use in standardized Cheddar and Mozzarella cheese making (Code of Federal Regulations, 2003). Concerns about on-farm UF of milk were addressed by maintaining a low operating temperature and using a unique membrane filtration system (Raghunath and Hibbard, 1997). There are 4 large, on-farm UF plants currently operating in the US.

Parmesan cheese is commonly manufactured from milk with a $\mathrm{CN}$ :fat ratio of 1.05 to 1.15 . Whole milk $\mathrm{CN}$ :fat ratio is much lower ( $0.68: 1)$; therefore, milk for Parmesan cheese manufacture is usually standardized by cream removal, which reduces cheese yield. Milk for Parmesan cheese manufacture may also be standardized with NDM. However, use of NDM can increase the lactose level in the serum phase of milk and thus increase the residual sugar in the cheese (unless water is added). This may result in an excessively low $\mathrm{pH}$ and discoloration of the cheese (i.e., browning) (Shannon, 1969). With the increased availability of cold, whole ultrafiltered milk (WUF) produced on-farm in the southwestern United States (Fassbender, 2001), Parmesan cheese manufacturers in Wisconsin are considering using this milk as another option for standardization purposes. The use of UF milk increases plant productivity by allowing more cheese to be made for the same number of vat fills and man-hours. In contrast to addition of NDM, UF milk does not result in high residual lactose in the cheese. However, the higher solids level in the cheese milk may require modification of the cheese manufacturing protocol, depending on the solids/protein content of the cheese- 
milk. A 5\% protein content in cheesemilk was selected as a protein level that should not cause too many problems in coagulation or excessive fat losses (Guinee et al., 1994). The reason for specifically selecting the solids levels $(-14.2 \%)$ that were used for the present study was that it gave approximately $5 \%$ protein content in the UF standardized cheesemilks. Another consideration in selecting this solids content $(\sim 5 \%$ protein; $\sim 14.2 \% \mathrm{TS}$ ) was that current Wisconsin regulations (Wisconsin Department of Agriculture, Trade \& Consumer Protection, 2002) require a higher pasteurization temperature $\left(74.4^{\circ} \mathrm{C}\right.$ for $\left.15 \mathrm{~s}\right)$ if the solids content of the milk is $>16 \%$. Cheesemakers are often reluctant to use very high pasteurization temperatures because this may cause cheeses to have higher moisture contents and may also affect the flavor and/or texture of the cheese (Banks and Muir, 1985; Marshall, 1986).

It has been suggested that during the warm UF of whole milk there may be partial homogenization of the fat and denaturation of whey protein (Green et al., 1983, 1984; Lawrence, 1989). These factors may contribute to impaired curd formation and/or increased susceptibility to lipolysis during cheese ripening (Walstra and Jenness, 1984; McMahon et al., 1993). Damage to the milk fat globule is less likely in larger industrial, single-pass UF systems where recirculation of the retentate is not necessary for the low concentration factors needed (i.e., $<2 \times$ ) for cheesemilk standardization. Guinee et al. (1994) suggested blending skim milk UF (SUF) retentate with cream as a preferred method of standardization of milk for Cheddar cheese manufacture as opposed to using WUF retentates.

There does not appear to be any previous reports describing the impact of cold UF retentates on cheese making properties, such as coagulation and yield. The objective of this study was to study coagulation properties, cheese yield, cheese composition, proteolysis, and lipolysis and to identify any modifications that may be necessary to use these UF retentates successfully for Parmesan cheese. The SUF retentate is also available commercially and would provide another option for standardization of milk. The cheese plant would not need to remove cream from their milk prior to blending with SUF, as would be the case if WUF was used. Therefore, we investigated the use of both WUF and SUF retentates for standardization of cheesemilks.

\section{MATERIALS AND METHODS}

\section{UF and Standardization}

Raw whole milk, raw skim milk, and cream were obtained from the University of Wisconsin-Madison dairy plant on the day before cheese making. Raw whole milk was partially skimmed to 2 different fat contents: $0.92 \pm 0.07 \%$ and $3.16 \pm 0.02 \%$. Low concentration factor UF (LCF-UF) was carried out by concentrating milk to $23 \%(12.4 \% \mathrm{CN})$ and $27 \%$ solids $(8.3 \%$ $\mathrm{CN})$ for raw skim and whole milks, respectively. The LCF-UF was performed at $<7^{\circ} \mathrm{C}$ by recirculation through a UF unit (APV Americas, Tonawanda, NY) fitted with 2 spiral-wound, polyethersulfone membranes (each with a molecular weight cut-off of 10,000 $\mathrm{Da}$ and membrane area of $5.57 \mathrm{~m}^{2}$; PTI Advanced Filtration, Oxnard, CA) that was modified by Membrane Systems Specialists (Wisconsin Rapids, WI). During the UF process, milk was cooled by a plate heat exchanger to maintain the low temperatures necessary for the cold UF process $\left(<7^{\circ} \mathrm{C}\right)$ when this operation is performed on farm. The retentates were then stored overnight at $4^{\circ} \mathrm{C}$ and then blended the following morning to give standardized cheesemilks.

Three types of cheesemilks were prepared: control, milk standardized with WUF retentate, and milk standardized with SUF retentate (Table 1). The control cheesemilk was standardized by cream removal to an average of $11.08 \%(2.59 \% \mathrm{CN})$ solids with a mean $\mathrm{CN}$ :fat ratio of $\sim 1.13$. The WUF cheesemilk was prepared by blending the WUF retentate with partlyskimmed milk ( $0.92 \%$ fat) to obtain WUF milk with $14.16 \%$ solids $(4.06 \% \mathrm{CN})$ with a mean $\mathrm{CN}$ :fat ratio of 1.13. The SUF cheesemilk was prepared by blending the SUF retentate with whole milk that was partially skimmed (3.16\% fat) and cream to obtain SUF cheesemilk with $14.23 \%$ solids $(4.07 \% \mathrm{CN})$ and a mean $\mathrm{CN}$ :fat ratio of $\sim 1.11$.

\section{Cheese Manufacture and Sampling Procedures}

The day after membrane processing, duplicate vats of Parmesan cheese were manufactured from each of 3 cheesemilks (control, WUF, and SUF) by a licensed cheesemaker in the University of Wisconsin-Madison dairy processing pilot plant using a traditional Parmesan manufacturing protocol. A second trial was carried out to replicate the experiment, starting with new batches of raw milk, raw skim milk, and cream that were also processed as in the first trial (giving a total of 12 cheeses). The order of vats was randomized. Prior to cheese making, the blended milks were pasteurized and then cooled to the ripening temperature of $33.4^{\circ} \mathrm{C}$. The control vats were filled with $227 \mathrm{~kg}$ of pasteurized milks. In the experimental vats, only $181 \mathrm{~kg}$ of standardized milks were used. The starters, comprising Streptococcus thermophilus (C90 or C110; Rhodia, Madison, WI) and Lactobacillus helveticus (LH32; Chr Hansen, Milwaukee, WI) were grown separately over- 
Table 1. Average weights and composition of the different milks, cream, and retentates used in the preparation of the UF standardized cheesemilks for the different treatments $(n=2)$.

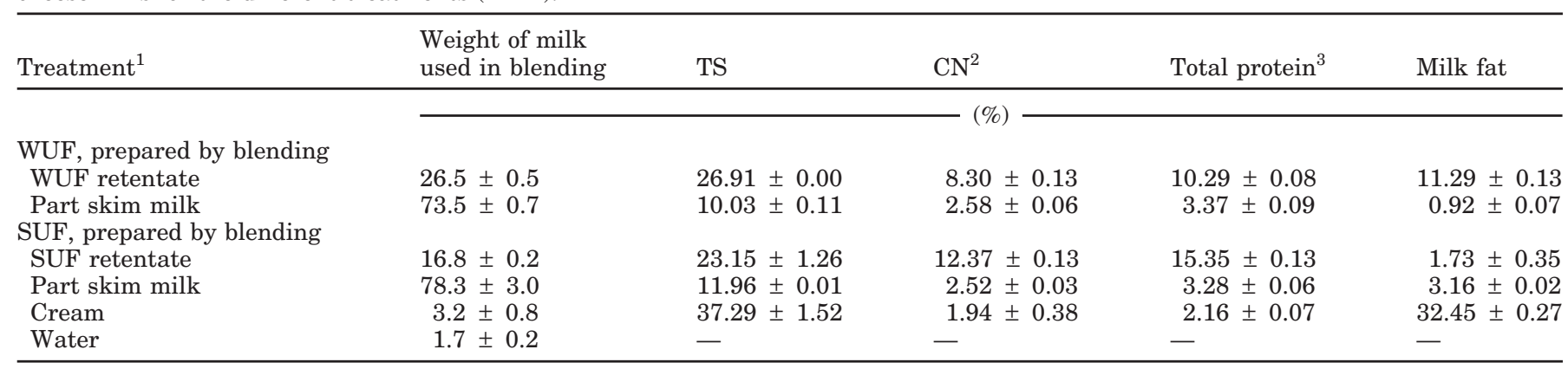

${ }^{1} \mathrm{WUF}=$ whole milk UF; SUF $=$ skim milk UF.

${ }^{2}($ Total $\% \mathrm{~N}-\%$ noncasein $\mathrm{N}) \times 6.36$.

${ }^{3}$ Total $\% \mathrm{~N} \times 6.35$.

night at $43^{\circ} \mathrm{C}(\mathrm{C} 90$ or $\mathrm{C} 110, \mathrm{pH} 4.60$ to 4.85 and $\mathrm{LH} 32$, $\mathrm{pH} 3.70$ to 3.90 ) in skim milk that had been heattreated at $82^{\circ} \mathrm{C}$ for $30 \mathrm{~min}$. The amount of starters added to each vat was based on the TS concentration (154 $\pm 2 \mathrm{~g}$ of starters $/ \mathrm{kg}$ of solids). Pasteurized control and experimental milks were inoculated with these thermophilic cultures at a rate of 17.5 and $21.9 \mathrm{~g} / \mathrm{kg}$ milk with a rod:coccus ratio of $8: 1$. In addition, directto-vat Lactobacillus casei (CR131) and Lactococcus lactis (CR213) adjunct cultures (Chr Hansen) were each added to the control and experimental milks at the rate of 17.7 and $22.1 \mathrm{mg} / \mathrm{kg}$ of milk, respectively. Following a 60-min ripening period, double strength chymosin (Chymostar; Rhodia) was added to the control and experimental milks at a rate of 75 and $94 \mu \mathrm{L} /$ $\mathrm{kg}$ of milk, respectively. The amount of rennet added to each vat was also based on TS concentration (660 $\pm 12 \mu \mathrm{L} / \mathrm{kg}$ of TS).

The coagula were cut on similar firmness as evaluated subjectively by an experienced licensed Wisconsin cheesemaker. The coagulum was cut with 4-mm knives at $\mathrm{pH} \sim 6.45$. The temperature of the vat was raised to the cooking temperature over $40 \mathrm{~min}$. After reaching the cooking temperature, each vat was cooked at that temperature $\left(48^{\circ} \mathrm{C}\right)$ with stirring for $30 \mathrm{~min}$, and then the whey was drained for $25 \mathrm{~min}$. The curd was packed into 9-kg Wilson hoops and pressed for $4 \mathrm{~h}$ at $\sim 20^{\circ} \mathrm{C}$. After pressing, the cheeses were placed in a warm room $\left(23.9\right.$ to $\left.26.7^{\circ} \mathrm{C}\right)$ overnight to ensure that all the sugars (lactose and/or galactose) were fermented by one day. The following morning, the cheeses were removed from the moulds and weighed. Following brining for $\sim 70 \mathrm{~h}$ at 3 to $5^{\circ} \mathrm{C}$, the cheeses were weighed again. The cheeses were then dried at $65 \%$ relative humidity and $12^{\circ} \mathrm{C}$ in a commercial drying facility until the target moisture of $\sim 32 \%$ was attained $(\sim 8 \mathrm{wk})$. The cheeses were vacuum-packaged in Cryovac stan- dard clear bags (9Fv86; Cryovac North America, Duncan, SC) and aged at $7^{\circ} \mathrm{C}$.

In the second trial, after the draining step, the curd in the control and experimental vats were presalted at the rate of 12.26 and $9.55 \mathrm{~g} / \mathrm{kg}$ of curd, respectively. In the second trial, the cheeses were brined for $~ 100$ $\mathrm{h}$ at 3 to $5^{\circ} \mathrm{C}$ (to help increase the salt content).

\section{Compositional Analyses of Milks, Wheys, and Cheeses}

All compositional analyses were carried out in triplicate. Milk, drain whey, and press whey samples were analyzed for fat by Mojonnier (AOAC, 2000), for protein (total percentage $\mathrm{N} \times 6.35$ ) by Kjeldahl (AOAC, 2000), for CN (AOAC, 2000), for lactose (AOAC, 2000), for TS (Green and Park, 1980) and for NPN (AOAC, 2000)

The cheeses were sampled after drying for compositional analysis. At the time of sampling, a quarter of the block was cut off; one-half of this quarter was completely ground and used for analysis. Cheese samples were analyzed for moisture (Marshall, 1992), fat (AOAC, 2000), pH by the quinhydrone method (Marshall, 1992), protein by Kjeldahl (AOAC, 2000), salt by chloride electrode method (model 926; Corning Glass Works, Medfield, MA; Johnson and Olson, 1985) and lactose and/or galactose (Anonymous, 1997). Proteolysis was monitored during ripening by measuring the amount of $12 \%$ TCA-soluble $\mathrm{N}$ at $0,2.5,6$, and $10 \mathrm{mo}$ (AOAC, 2000). Individual FFA were determined using the modified procedure of $\mathrm{Ha}$ and Lindsay (1990) at 0 , $2.5,6$, and 10 mo as described recently by Jaeggi et al. (2003).

\section{Fat, N, and TS Recovery and Cheese Yield}

A mass balance was carried out for each vat of the cheese. Milk and drain whey were weighed to $\pm 0.1 \mathrm{~kg}$ 
(milk: model 31-1822-FD and drain whey: model 8140; Toledo Scale Co., Toledo, $\mathrm{OH})$, press whey was weighed to $\pm 0.1 \mathrm{~kg}$ (model MSG-500 Series Electronic Scales; Mars Scale Group, Niagara Falls, NY), and cheese was weighed to $\pm 0.01 \mathrm{~kg}$ (model CW-80I-2A; Rice Lake Weighing Systems, Rice Lake, WI). The percentage of fat, N, or TS recovered in the cheese, drain whey, and press whey was calculated as the total amount of fat, $\mathrm{N}$, or TS in each one of these products divided by the total amount of fat, N, or TS in the original standardized milk and multiplied by 100 .

Actual yield was calculated for each vat of cheese as the weight of the cheese divided by the weight of the original standardized milk (including the amount of cultures added during the cheese manufacture) multiplied by 100 . Actual cheese yield was also adjusted to the target cheese moisture content (for Parmesan, this was $32 \%$ ) to eliminate the effects of variations in moisture from vat to vat and among treatments on the yield evaluation.

\section{Rheological Properties During the Rennet Coagulation of Cheesemilks}

Rennet-induced milk gels are viscoelastic, and their small deformation rheological properties can be determined by dynamic low amplitude oscillatory rheometry by measuring storage modulus $\left(\mathbf{G}^{\prime}\right)$, loss modulus, and loss tangent (Zoon et al., 1988; Van Vliet et al., 1989; Lucey, 2002). The rheological characteristics of the standardized cheesemilks during renneting were measured at $33.4 \pm 0.1^{\circ} \mathrm{C}$ in a UDS 200 Physica rheometer (D-70564; Physica Messtechnik, Stuttgart, Germany) operating in oscillation mode at a frequency of $0.1 \mathrm{~Hz}$ and a strain of $1 \%$. The measuring body (Z3 DIN) consisted of 2 coaxial cylinders (diameters, 25.0 and $27.5 \mathrm{~mm}$ ). A profiled (serrated) bob was used in this couette-type fixture. As the starters and rennet were added based on the amount of solids in the standardized milks, we used a different milk volume for the control $(50 \mathrm{~mL})$ and experimental milks $(\sim 40 \mathrm{~mL})$ to facilitate the addition of the appropriate rennet and starter concentration to these milk samples. A sample of the standardized milk was taken from each cheese vat (prior to the addition of starter or rennet), and all of the milk samples were stored at $4^{\circ} \mathrm{C}$. Prior to testing, this milk sample was warmed to $33.4^{\circ} \mathrm{C}$ for about 30 min in a water bath and then inoculated with the starters (109.1 mg of C90 or C110 and $1.529 \mathrm{~g}$ of LH32). An hour later, $100 \mu \mathrm{L}$ of distilled water containing $3.74 \mu \mathrm{L}$ of double strength chymosin (Chymostar) was added to the milk and mixed thoroughly; $\sim 13 \mathrm{~mL}$ of the mixture was immediately placed in the cup (maintained at $33.4^{\circ} \mathrm{C}$ ) of the rheometer. Vegetable oil was layered onto the surface of the milk to prevent evaporation during coagulation. Measurements were started $120 \mathrm{~s}$ after rennet addition and were taken at $60-\mathrm{s}$ intervals until the time when the cheesemaker chose to cut the coagulum. This cutting time varied for each of the milk samples. Gelation time was defined as the point when gels had a $\mathrm{G}^{\prime} \geq 0.1 \mathrm{~Pa}$ (i.e., when $\mathrm{G}^{\prime}$ became greater than noise level).

To determine the resistance of the coagulum to cutting, we studied the large deformation properties of the rennet gels using the constant shear rate technique for determining apparent yield stress and shear deformation at yielding as described previously for acid milk gels (Lucey et al., 1997). Gels were made in situ as described previously and were sheared at a constant shear rate of $\sim 0.01 / \mathrm{s}$ at $33.4^{\circ} \mathrm{C}$ starting at the cutting time specified by our cheesemaker. The gels were subjected to the constant shearing up to yielding of the gel, which is defined as the point when the shear stress started to decrease (Lucey et al., 1997).

\section{Experimental Design and Statistical Analysis}

Two replicate cheese making trials were carried out; in each trial, 3 standardized milks (i.e., part-skimmed milk or control, milk standardized with WUF retentate, and milk standardized with SUF retentate) were used to make Parmesan cheese. A $3 \times 2$ complete randomized block design, which incorporated all 3 treatments in duplicate and 2 blocks (replicate trials) were used for analysis of the response variables relating to milk, cheese, and whey composition and coagulation properties. Analysis of variance was carried out using the PROC GLM procedure of SAS (version 8.2; SAS Institute, Inc., Cary, NC). In the ANOVA model, the 3 differently standardized milks (different treatments) were analyzed as a discontinuous variable while cheese making day (i.e., different batch of milk) was blocked. Duncan's or Scheffe's multiple-comparison test was carried out to evaluate differences in the treatment means at a significance level of $P<0.05$.

A split-plot design was used to monitor the effects of treatment and time of aging and their interactions on $\mathrm{pH}$, proteolysis (12\% TCA-soluble $\mathrm{N}$ expressed as a percentage of total $\mathrm{N}$ ), and the amount of individual FFA formed during ripening. For the whole plot factor, treatment was analyzed as a discontinuous variable, while cheese making day was blocked. For the subplot factor analysis, age and the quadratic form of age (age $\times$ age) were treated as continuous variables. The interactive term treatment $\times$ cheese making day was treated as the error term for the treatment effect. Analysis of variance for the split-plot design was carried out using the PROC GLM procedure of SAS. 
Table 2. Compositions of pasteurized standardized milk, whey, press whey, and cheese $(\mathrm{n}=4)$.

\begin{tabular}{|c|c|c|c|c|c|}
\hline \multirow[b]{2}{*}{ Component } & \multicolumn{3}{|c|}{ Treatment } & \multirow[b]{2}{*}{ SEM } & \multirow[b]{2}{*}{$P$ value } \\
\hline & Control & $\begin{array}{l}\text { Whole milk } \\
\text { UF }\end{array}$ & $\begin{array}{l}\text { Skim milk } \\
\text { UF }\end{array}$ & & \\
\hline \multicolumn{6}{|l|}{ Standardized cheesemilk } \\
\hline TS, \% & $11.08^{\mathrm{b}}$ & $14.16^{\mathrm{a}}$ & $14.23^{\mathrm{a}}$ & 0.069 & $<0.0001$ \\
\hline Milk fat, \% & $2.29^{\mathrm{b}}$ & $3.59^{\mathrm{a}}$ & $3.66^{\mathrm{a}}$ & 0.024 & $<0.0001$ \\
\hline Total protein, ${ }^{1} \%$ & $3.26^{\mathrm{b}}$ & $5.06^{\mathrm{a}}$ & $5.08^{\mathrm{a}}$ & 0.022 & $<0.0001$ \\
\hline True protein, ${ }^{2} \%$ & $3.08^{\mathrm{b}}$ & $4.88^{\mathrm{a}}$ & $4.90^{\mathrm{a}}$ & 0.023 & $<0.0001$ \\
\hline $\mathrm{CN}^{3} \%$ & $2.59^{\mathrm{b}}$ & $4.06^{\mathrm{a}}$ & $4.07^{\mathrm{a}}$ & 0.025 & $<0.0001$ \\
\hline NPN, \% & $0.027^{\mathrm{b}}$ & $0.028^{\mathrm{a}}$ & $0.028^{\mathrm{a}}$ & 0.001 & 0.03 \\
\hline $\mathrm{CN}$ to total protein, \% & 79.44 & 80.24 & 80.12 & 0.163 & $\mathrm{NS}^{4}$ \\
\hline $\mathrm{CN}$ to true protein, $\%$ & $84.10^{\mathrm{a}}$ & $83.20^{\mathrm{b}}$ & $82.96^{\mathrm{b}}$ & 0.135 & 0.01 \\
\hline Whey protein ${ }^{5} \%$ & $0.49^{b}$ & $0.82^{\mathrm{a}}$ & $0.83^{\mathrm{a}}$ & 0.004 & $<0.0001$ \\
\hline Whey protein in serum phase, ${ }^{6} \%$ & $0.52^{\mathrm{b}}$ & $0.89^{\mathrm{a}}$ & $0.90^{\mathrm{a}}$ & 0.004 & $<0.0001$ \\
\hline Lactose, $\%$ & $4.54^{\mathrm{a}}$ & $4.35^{\mathrm{b}}$ & $4.36^{\mathrm{b}}$ & 0.029 & 0.02 \\
\hline Lactose in serum phase, ${ }^{7} \%$ & 4.77 & 4.71 & 4.73 & 0.034 & NS \\
\hline $\mathrm{CN}$ :fat ratio & 1.13 & 1.13 & 1.11 & 0.010 & NS \\
\hline \multicolumn{6}{|l|}{ Drain whey } \\
\hline TS, \% & $6.70^{\mathrm{b}}$ & $7.31^{\mathrm{a}}$ & $7.28^{\mathrm{a}}$ & 0.051 & $<0.0001$ \\
\hline Milk fat, \% & $0.23^{\mathrm{c}}$ & $0.39^{\mathrm{a}}$ & $0.34^{\mathrm{b}}$ & 0.007 & $<0.0001$ \\
\hline Total protein, \% & $0.85^{\mathrm{b}}$ & $1.30^{\mathrm{a}}$ & $1.33^{\mathrm{a}}$ & 0.010 & $<0.0001$ \\
\hline Lactose, $\%$ & 4.81 & 4.76 & 4.78 & 0.037 & NS \\
\hline \multicolumn{6}{|l|}{ Press whey } \\
\hline $\mathrm{TS}, \%$ & $8.59^{b}$ & $9.13^{\mathrm{a}}$ & $9.11^{\mathrm{a}}$ & 0.110 & 0.02 \\
\hline Milk fat, \% & 0.61 & 0.94 & 0.66 & 0.049 & 0.25 \\
\hline Total protein, \% & $0.96^{\mathrm{b}}$ & $1.37^{\mathrm{a}}$ & $1.39^{\mathrm{a}}$ & 0.012 & $<0.0001$ \\
\hline Lactose, $\%$ & 4.54 & 4.54 & 4.54 & 0.040 & 0.99 \\
\hline \multicolumn{6}{|l|}{ Cheese (before brining) } \\
\hline Moisture at $1 \mathrm{~d}, \%$ & 40.27 & 40.63 & 40.52 & 0.194 & NS \\
\hline \multicolumn{6}{|l|}{ Cheese (after drying) } \\
\hline Moisture, \% & $30.50^{\mathrm{b}}$ & $30.76^{\text {ba }}$ & $32.44^{\mathrm{a}}$ & 0.307 & 0.02 \\
\hline Fat, $\%$ & 28.48 & 27.95 & 27.87 & 0.169 & NS \\
\hline Total protein ${ }^{8}, \%$ & 33.26 & 33.02 & 32.15 & 0.240 & NS \\
\hline Salt, $\%$ & 1.89 & 1.66 & 1.89 & 0.085 & 0.18 \\
\hline MNFS, ${ }^{9} \%$ & $42.60^{\mathrm{b}}$ & $42.69^{\mathrm{b}}$ & $44.97^{\mathrm{a}}$ & 0.349 & 0.01 \\
\hline FDM,${ }^{10} \%$ & 40.98 & 40.37 & 41.25 & 0.145 & NS \\
\hline $\mathrm{SM}^{111} \%$ & 6.20 & 5.40 & 5.72 & 0.287 & 0.12 \\
\hline \\
\hline \multicolumn{6}{|c|}{${ }^{1}$ Total $\% \mathrm{~N} \times 6.35$} \\
\hline \multicolumn{6}{|c|}{${ }^{2}($ Total $\% \mathrm{~N}-\% \mathrm{NPN}) \times 6.35$} \\
\hline \multicolumn{6}{|c|}{${ }^{3}($ Total $\% \mathrm{~N}-\%$ noncasein $\mathrm{N}) \times 6.36$} \\
\hline \multicolumn{6}{|c|}{${ }^{4} F$ test for full statistical model, $P>0.05$. } \\
\hline \multicolumn{6}{|c|}{${ }^{5}$ True protein $-\mathrm{CN}$. } \\
\hline \multicolumn{6}{|c|}{${ }^{6} \%$ Whey protein $/(100 \%-\%$ fat $-\% \mathrm{CN})$} \\
\hline \multicolumn{6}{|c|}{$7 \%$ Lactose $/(100 \%-\%$ fat $-\% \mathrm{CN})$} \\
\hline \multicolumn{6}{|c|}{${ }^{8}$ Total \% $\mathrm{N} \times 6.31$} \\
\hline \multicolumn{6}{|c|}{${ }^{9} \mathrm{MNFS}=$ Moisture in the nonfat substance of the cheese. } \\
\hline${ }^{10} \mathrm{FDM}=$ Fat content on a dry we & basis. & & & & \\
\hline${ }^{11} \mathrm{SM}=$ Salt in the moisture phas & the chee & & & & \\
\hline
\end{tabular}

\section{Sensory Analysis}

Informal sensory assessment was performed at 2.5, 6 , and 10 mo by 2 experienced licensed cheese graders.

\section{RESULTS AND DISCUSSION}

\section{UF Retentate and Standardized Cheesemilk Composition}

The total protein, fat, TS, and CN contents of the WUF retentates were $10.29,11.29,26.91$, and $8.30 \%$, respectively (Table 1). The SUF retentates had solid content of $23.15 \%$, total protein of $15.35 \%, \mathrm{CN}$ content of $12.37 \%$ and fat content of $1.73 \%$.

As expected, the TS, fat, total protein, true protein, and CN contents were significantly higher in the milks standardized with UF retentates (Table 2). There were no significant differences in the composition of milks standardized with UF retentates. The lactose content of the control milk was significantly $(P<0.05)$ higher than the UF standardized milks, as lactose permeates through the UF membrane. The lower lactose content 
Table 3. Fat, N, and solids recovery for Parmesan cheeses $(\mathrm{n}=4)$.

\begin{tabular}{|c|c|c|c|c|c|}
\hline \multirow[b]{2}{*}{ Component recovery } & \multicolumn{3}{|c|}{ Treatment } & \multirow[b]{2}{*}{ SEM } & \multirow[b]{2}{*}{$P$ value } \\
\hline & Control & $\begin{array}{l}\text { Whole milk } \\
\text { UF }\end{array}$ & $\begin{array}{l}\text { Skim milk } \\
\text { UF }\end{array}$ & & \\
\hline \multicolumn{6}{|l|}{$\%$ Fat recovery } \\
\hline Cheese & 91.91 & 91.44 & 91.96 & 0.234 & NS \\
\hline Drain whey & $8.94^{\mathrm{a}}$ & $9.16^{\mathrm{a}}$ & $7.87^{\mathrm{b}}$ & 0.171 & $<0.01$ \\
\hline Pressed whey & 0.29 & 0.53 & 0.26 & 0.060 & NS \\
\hline Total & 101.14 & 101.13 & 100.09 & & \\
\hline \multicolumn{6}{|l|}{$\% \mathrm{~N}$ recovery } \\
\hline Cheese & $76.09^{b}$ & $77.63^{\mathrm{a}}$ & $77.65^{\mathrm{a}}$ & 0.323 & $<0.05$ \\
\hline Drain whey & $23.48^{\mathrm{a}}$ & $21.36^{\mathrm{b}}$ & $21.68^{\mathrm{b}}$ & 0.430 & $<0.05$ \\
\hline Pressed whey & 0.30 & 0.54 & 0.35 & 0.043 & NS \\
\hline Total & 99.87 & 99.53 & 99.68 & & \\
\hline \multicolumn{6}{|l|}{$\%$ Solids recovery } \\
\hline Cheese & $46.29^{b}$ & $57.43^{\mathrm{a}}$ & $57.30^{\mathrm{a}}$ & 0.158 & $<0.01$ \\
\hline Drain whey & $54.12^{\mathrm{a}}$ & $43.05^{\mathrm{b}}$ & $43.00^{\mathrm{b}}$ & 0.137 & $<0.01$ \\
\hline Pressed whey & 0.78 & 1.49 & 0.89 & 0.099 & 0.14 \\
\hline Total & 101.19 & 101.97 & 101.19 & & \\
\hline$\%$ Drain whey & $89.42^{\mathrm{a}}$ & $83.22^{\mathrm{b}}$ & $83.45^{\mathrm{b}}$ & 0.199 & $<0.01$ \\
\hline$\%$ Pressed whey & 1.02 & 2.08 & 1.73 & 0.137 & NS \\
\hline$\%$ Cheese (before drying) & $8.17^{\mathrm{b}}$ & $13.01^{\mathrm{a}}$ & $13.10^{\mathrm{a}}$ & 0.067 & $<0.01$ \\
\hline Total & 98.61 & 98.31 & 98.28 & & \\
\hline Actual yield $(\%)$ & $7.38^{\mathrm{b}}$ & $11.74^{\mathrm{a}}$ & $12.06^{\mathrm{a}}$ & 0.121 & $<0.01$ \\
\hline $\begin{array}{l}\text { Averaged, moisture-adjusted yield } \\
\text { to } 32 \% \text { moisture }(\%)\end{array}$ & 7.55 & 11.96 & 11.98 & & \\
\hline
\end{tabular}

in the UF standardized milks is due to the increased fat and $\mathrm{CN}$ content, as the lactose contents in the serum phase $(100-\%$ fat $-\% \mathrm{CN})$ of all milks were similar (Table 2). All milks were standardized to a similar CN:fat ratio. Total solids and total protein contents of wheys from both WUF and SUF standardized cheeses were significantly higher $(P<0.01)$ than the control wheys. There was significantly higher fat $(P<$ 0.01 ) in the WUF standardized cheese whey than that in the SUF standardized whey and control wheys. This result is consistent with the lower fat recovery as cheese in milk standardized with WUF retentate (Table 3).

\section{Cheese Composition}

Moisture contents of all 3 cheeses were similar $(\sim 40 \%)$ at $1 \mathrm{~d}$, i.e., prior to brining (Table 2$)$. However, after drying for a 2-mo period, the moisture contents of the SUF-fortified cheeses were slightly higher ( $32 \%)$ than those of the control and WUF cheeses $(\sim 30 \%)$. For the same drying period, the control and WUFfortified cheeses lost somewhere between 1 to $2 \%$ more moisture than the SUF cheeses. The moisture in the nonfat substance in the control and WUF-fortified cheeses was lower than that in the SUF cheeses. The fat and protein contents of the UF-fortified cheeses were lower than that in the control cheeses. The fat in $\mathrm{DM}$ of the cheeses was within the typical range of values (40 to 41\%; wt/wt) for Parmesan cheese. There was no residual lactose or galactose in any of the cheeses at one day (results not shown). The other compositional parameters were not significantly different between treatments.

\section{Fat Recovery}

Although there were no statistically significant differences in the fat recoveries between the control and UF cheeses, fat recovered in the control or SUF standardized cheeses tended to be slightly higher than that in the WUF standardized cheeses (Table 3). The amount of fat lost in the drain whey obtained from WUF standardized cheese was similar to that of the control, but there were significantly lower fat losses in the drain whey from SUF standardized milk (Table 3). We expected that both WUF and SUF should have had greater fat recoveries than control cheese. The LCF-UF of cheesemilk to $<5 \%$ protein results in increased fat recovery (Guinee et al., 1994). However, the fat recovery in the WUF cheese was lower than SUF and similar to control. The higher fat loss during cheese making for milks standardized with WUF was probably due to some damage to the milk fat globule during the recirculation process that we used to concentrate the whole milk. In UF units with large membrane areas that are common in the dairy industry, this should be less of a problem, as there would be little need for recirculation (even a single pass could be sufficient to concentrate the milk to the solid levels 
Table 4. Mean $(n=4)$ lactose and true protein composition in whey normalized to concentrations that would be produced from $100 \mathrm{~kg}$ of standardized milk.

\begin{tabular}{|c|c|c|c|c|c|c|c|}
\hline \multirow[b]{2}{*}{ Treatment } & \multicolumn{7}{|c|}{ Total amount in cheese whey } \\
\hline & $\begin{array}{l}\text { Total } \\
\text { whey }^{1}\end{array}$ & Lactose & $\begin{array}{l}\text { True } \\
\text { protein }\end{array}$ & $\mathrm{TS}$ & $\begin{array}{l}\text { Total } \\
\text { fat }\end{array}$ & $\begin{array}{l}\text { Lactose/ } \\
\text { total solids }\end{array}$ & $\begin{array}{l}\text { True protein } \\
\text { total solids }\end{array}$ \\
\hline & & & $-(\mathrm{kg})$ & & & & \%) \\
\hline Control & $90.44^{\mathrm{a}}$ & $4.35^{\mathrm{a}}$ & $0.580^{\mathrm{b}}$ & $6.08^{b}$ & $0.209^{c}$ & $71.56^{\mathrm{a}}$ & $9.54^{\mathrm{b}}$ \\
\hline Whole milk UF & $85.30^{\mathrm{b}}$ & $4.05^{\mathrm{b}}$ & $0.926^{\mathrm{a}}$ & $6.30^{\mathrm{a}}$ & $0.349^{\mathrm{a}}$ & $64.20^{\mathrm{b}}$ & $14.68^{\mathrm{a}}$ \\
\hline Skim milk UF & $85.18^{\mathrm{b}}$ & $4.06^{\mathrm{b}}$ & $0.928^{\mathrm{a}}$ & $6.23^{\mathrm{a}}$ & $0.297^{\mathrm{b}}$ & $65.21^{\mathrm{b}}$ & $14.88^{\mathrm{a}}$ \\
\hline SEM & 0.096 & 0.028 & 0.005 & 0.037 & 0.008 & 0.336 & 0.047 \\
\hline$P$ value & $<0.01$ & $<0.01$ & $<0.01$ & $<0.05$ & $<0.01$ & $<0.01$ & $<0.01$ \\
\hline
\end{tabular}

${ }^{\mathrm{a}, \mathrm{b}, \mathrm{c}}$ Means within the same column without a common superscript $\operatorname{differ}(P<0.05)$.

${ }^{1}$ Total whey $=$ drain whey + press whey.

needed for this LCF-UF). The low fat losses in the drain whey obtained from the SUF milks suggest that the observed fat losses were indeed due to our UF system and were not due to the high solids cheesemilk in the vat. It has been our experience that the use of WUF retentates in Cheddar produced commercially and without recirculation did not increase fat loss in whey. Guinee et al. (1994) observed increasing amounts of fat losses in the drain whey during Cheddar cheese manufacture when milk protein levels were $>5 \mathrm{~g} / 100 \mathrm{~g}$. In our studies, even though, the milk protein levels in both SUF and WUF standardized cheesemilks were about $5.1 \mathrm{~g} / 100 \mathrm{~g}$, this effect was not observed as less fat was lost in the SUF standardized drain whey compared with control whey. Higher fat losses can occur if gels are cut too firm (likely to occur with high CN milks) or cut too soft followed by rapid stirring (Johnston et al., 1991; Johnson et al., 2001). Modifications to the coagulation conditions and vat cutting operations may allow higher protein contents to be used for cheese making without excessive fat losses.

\section{N Recovery}

Nitrogen recoveries were higher in the UF cheeses than the control cheeses (Table 2), and this was probably caused by higher protein in the serum phase in the UF milks (Table 1). Another explanation is that the curds were more resistant to shattering during stirring and retained more $\mathrm{CN}$ during cheese making compared with gels from the control milk; the significantly $(P<0.05)$ lower $\mathrm{N}$ losses in the drain whey of UF standardized cheeses (Table 2) support this suggestion. There was significantly $(P<0.01)$ higher recovery of solids in the WUF and SUF standardized cheeses compared with the control cheeses (Table 2), because cheeses made with UF retentates were manufactured from milks with high $\mathrm{CN}(\sim 96 \%$ of $\mathrm{CN}$ is available for conversion into cheese; Lucey and Kelly, 1994), and high fat and low lactose contents relative to control (most lactose ends up in drain whey). Thus, it was not surprising that cheesemilk with high $\mathrm{CN}$ and fat contents and low lactose levels has much higher solids recovery in cheese.

\section{Whey Composition}

Another important aspect of using higher solids milks is the reduction in the amount of drain whey produced during cheese making (Table 4). For example, drain whey was $\sim 90 \%$ of the mass derived from cheesemilk in cheeses made from control milks but decreased to $\sim 85 \%$ in the WUF and SUF standardized milks. This result suggests that when cheese plants use higher solids milks they produce significantly less whey volume, so there is less whey for processing. Lactose levels were also significantly $(P<0.01)$ lower in whey from milks standardized with UF retentates while the true protein, solids, and fat contents were higher. The whey produced from UF standardized milks had a lower proportion of lactose in the TS of whey ( 64 to $65 \%)$ compared with control milks $(\sim 71 \%)$. Whey produced from concentrated milks had a significantly $(P<0.01)$ higher level of true protein as a percentage of TS $(\sim 15 \%)$ compared with control ( 9\%). This was due to the loss of lactose as well as the loss of NPN during the UF process. This would make the whey from UF standardized milks more valuable, especially in plants manufacturing whey protein concentrates.

\section{Coagulation Properties}

The rheological properties of rennet-induced milk gels are shown in Table 5. There were no statistically significant differences in any of the properties of gels made with WUF and SUF retentates. The CN concentration was higher in the UF standardized milks, and rennet was added on a solids basis rather on the vol- 
Table 5. Effects of higher solids on the rheological properties of rennet-induced milk gels.

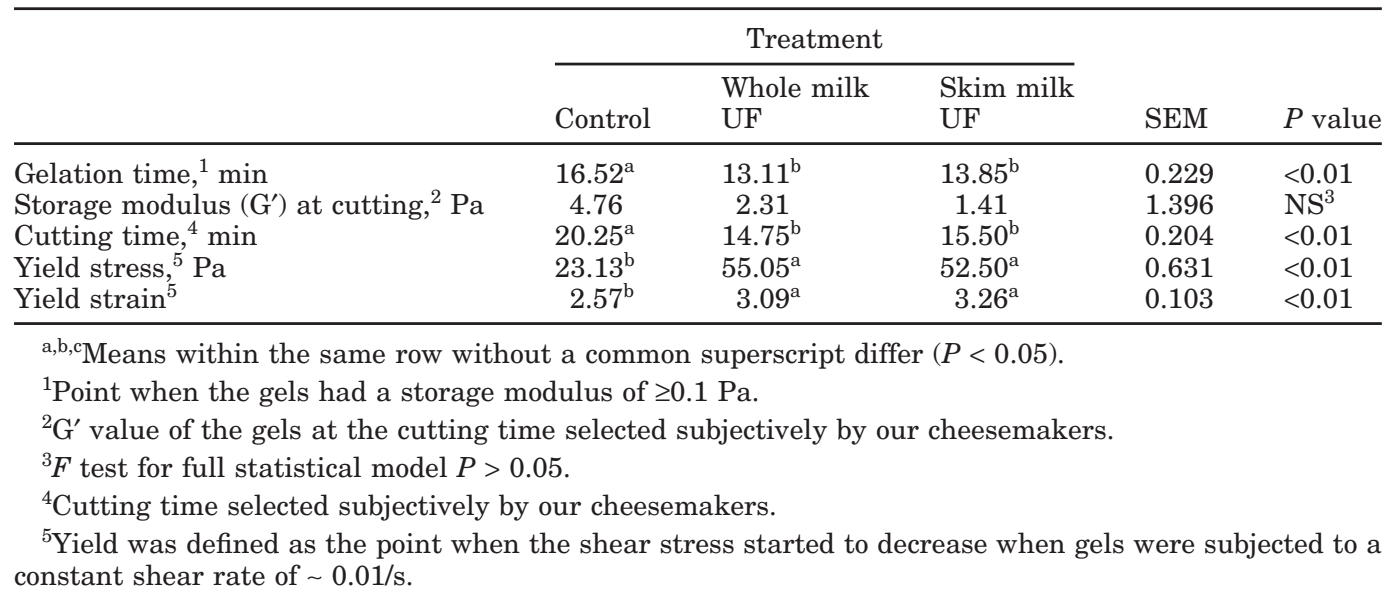

ume of milk so that the rennet:solids ratio $(660 \pm 12$ $\mu \mathrm{L} / \mathrm{kg}$ TS) was kept the same for both the control and concentrated milks. The gelation time determined by the rheometer was significantly $(P<0.01)$ longer in the control milk compared with the UF standardized milks, which were not significantly different from each other (Table 5). Ultrafiltration standardized milks also had shorter cutting times, in agreement with the results of Creamer et al. (1987). Our cheesemakers cut the coagulum on firmness evaluated subjectively, rather than time, and they appeared to cut the gel at a very consistent $G^{\prime}$ value, as there were no significant differences in the $G^{\prime}$ values at cutting for any of the treatments (Table 5). The $\mathrm{G}^{\prime}$ values at cutting were low $(<5 \mathrm{~Pa})$ compared with some other reports, e.g., Bohlin et al. (1984) reported that the $\mathrm{G}^{\prime}$ value at cut-

Table 6. Mean squares, probabilities (in parentheses), and $\mathrm{R}^{2}$ for $\mathrm{pH}$ and $12 \%$ TCA-soluble $\mathrm{N}$ during ripening age of Parmesan cheese at $12^{\circ} \mathrm{C}$ for $10 \mathrm{mo}$.

\begin{tabular}{lccc}
\hline Factor & $\mathrm{df}$ & $\mathrm{pH}$ & $\%$ Proteolysis \\
\hline Whole plot & & & \\
Treatment (T) & 1 & 0.0006 & 0.435 \\
& & $(0.86)$ & $(0.87)$ \\
Day of cheesemaking (D) & 2 & $0.130^{*}$ & 17.312 \\
& & $(0.03)$ & $(0.13)$ \\
Error $(\mathrm{T} \times \mathrm{D})$ & 2 & 0.003 & 2.831 \\
Subplot & & & \\
Age (A) & 1 & $0.205^{* *}$ & $344.177^{* * *}$ \\
& & $(<0.001)$ & $(<0.001)$ \\
$\mathrm{A} \times \mathrm{A}$ & 1 & $0.159^{* *}$ & $78.699^{* *}$ \\
& & $(<0.001)$ & $(<0.001)$ \\
$\mathrm{A} \times \mathrm{T}$ & 2 & 0.0005 & 2.089 \\
& & $(0.79)$ & $(0.285)$ \\
$\mathrm{A} \times \mathrm{A} \times \mathrm{T}$ & 2 & 0.0001 & 1.834 \\
& & $(0.94)$ & $(0.330)$ \\
Error & 36 & 0.002 & 1.605 \\
$\mathrm{R}^{2}$ & & 0.823 & 0.962 \\
\hline
\end{tabular}

$* 0.01<P \leq 0.05$.

$* * P \leq 0.01$. ting was in the range 30 to $40 \mathrm{~Pa}$ (measured at 0.5 $\mathrm{Hz}$ ), whereas Guinee et al. (1994) and O'Callaghan et al. (1999) cut the gels at 16 to $20 \mathrm{~Pa}$ (using a frequency of $1 \mathrm{~Hz}$ ) from concentrated and control milks. The use of a higher frequency would increase the $G^{\prime}$ value at cutting, as $G^{\prime}$ obeys a power law relation with frequency with an exponent of $\sim 0.23$ to 0.25 (Lucey, 2002). These differences in the $\mathrm{G}^{\prime}$ at cutting presumably reflect differences in the subjective selection by the cheesemakers of an appropriate coagulum firmness at which to cut the gel. In our experiments, the $G^{\prime}$ at cutting for coagula made from control milk tended to be slightly higher than those made from UF standardized milk (Table 5). Prior experience by our cheesemakers in using concentrated milks resulted in their decision to initiate cutting as soon as a soft gel was formed. The rapid rate in gel firming in higher protein milks made it difficult for them to cut the coagulum if they delayed the cutting time. This has practical implications for the cheese industry. In large, enclosed cheese vats, it is harder to monitor the onset of gelation, and these vats have longer cutting cycles.

The yield stress value, i.e., the force required to break the gel network, of both the higher solids milks were approximately 2 -fold greater than those of control milks (Table 5). The high yield stress in concentrated milk was due to several factors: primarily, the increased $\mathrm{CN}$ content, which is the structural forming material of the gel matrix, and also the rapid rate of gel formation in the UF milks such that the gels were still increasing in firmness during the slow shear rate test. Yield strain values were significantly $(P<0.01)$ lower in coagula made from control milks, reflecting a shorter or more brittle gel structure. Although the $\mathrm{G}^{\prime}$ values at cutting have been reported in several studies (e.g., Bohlin et al., 1984), the cutting operation is a large deformation process, so it is not clear how 


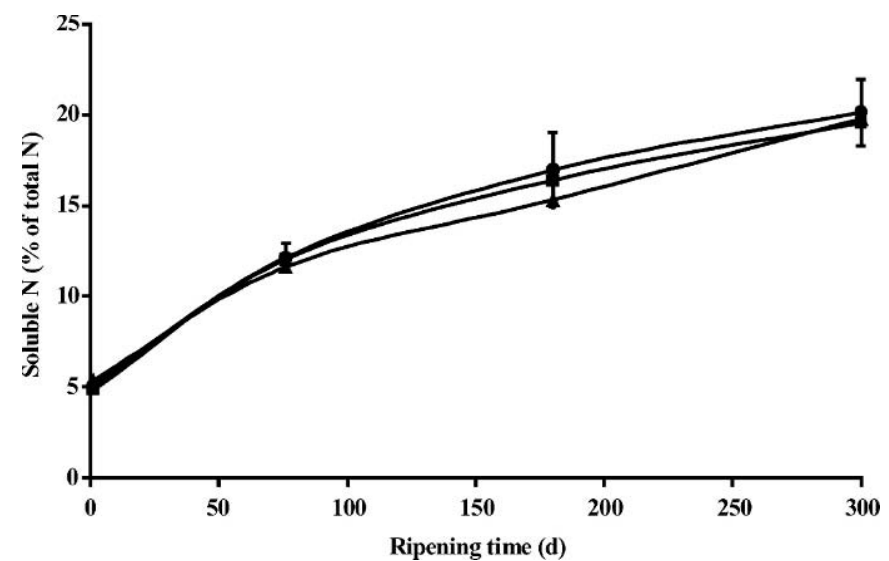

Figure 1. Twelve percent TCA-soluble $\mathrm{N}$ as a percentage of total $\mathrm{N}$ for control cheese ( $\boldsymbol{\Delta}$ ), whole milk UF cheeses ( $\mathbf{\square})$, and skim milk UF cheeses ( ) during $300 \mathrm{~d}$ of ripening of Parmesan cheeses at $12^{\circ} \mathrm{C}$. Vertical bars represent standard deviations.

useful a small deformation rheological parameter such as $\mathrm{G}^{\prime}$ is. Probably, the yield stress parameter is a better indicator of the resistance to cutting.

\section{Cheese Ripening and Grading}

Previous studies (Green et al., 1981; Green, 1985; Creamer et al., 1987; Spangler et al., 1990; Guinee et al., 1994) have shown that increasing milk protein concentration resulted in slower proteolysis in cheeses when rennet addition was based on a milk volume basis. In our study, the rennet:solids ratio was kept the same for both the control and concentrated milks, and the use of higher solids milks did not result in any significant difference in the formation of $12 \%$ TCAsoluble $\mathrm{N}$ during cheese ripening (Table 6; Figure 1). As expected, age had a significant effect on $12 \%$ TCAsoluble $\mathrm{N}$ production (Table 6 ). The $\mathrm{pH}$ values of the cheeses were not significantly different during ripening (Table 6; Figure 2), and this was probably because the lactose contents in the serum phase of all 3 milks were similar. The $\mathrm{pH}$ increased from 5.1 to about 5.3 during the drying period, that is, during the first 2 mo; thereafter, there was a slight decrease with increasing age.

Parmesan flavor has not been as extensively studied as Cheddar or Emmental (Reineccius, 2000). It is generally assumed that FFA (short or branched-chain) play an important role in the determination of flavor and aroma (Woo and Lindsay, 1984; Woo et al., 1984). Although Parmesan cheese should not exhibit rancid flavors, fatty acids are also needed for the formation of various fruity esters, such as ethyl butanoate and ethyl hexanoate, which are believed to be important in the characteristic fruity flavor of Parmesan (Qian

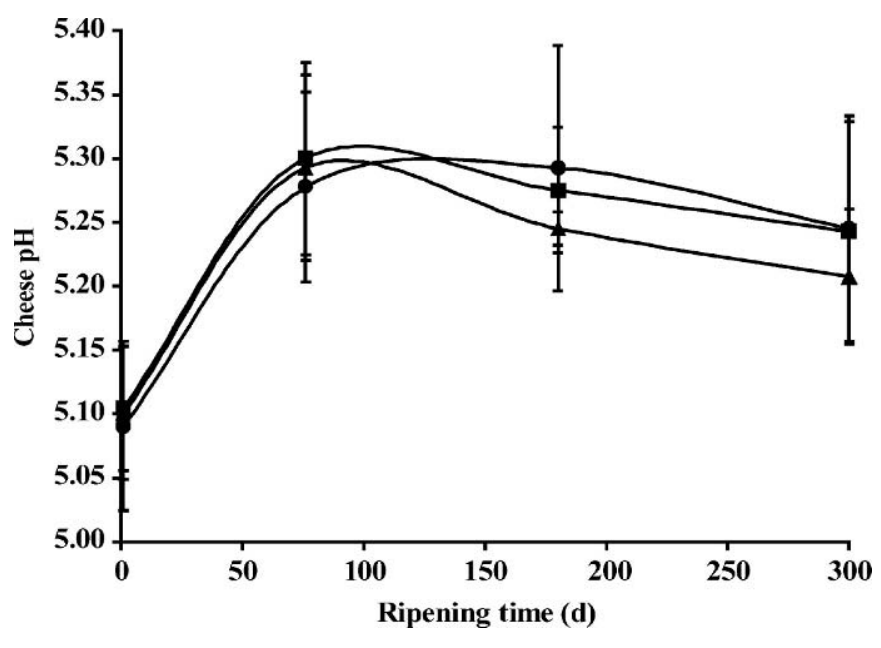

Figure 2. $\mathrm{pH}$ for control cheese ( $\mathbf{\Delta})$, whole milk UF cheeses ( $\mathbf{\square})$, and skim milk UF cheeses ( ) during $300 \mathrm{~d}$ of ripening of Parmesan cheeses at $12^{\circ} \mathrm{C}$. Vertical bars represent standard deviations.

and Reineccius, 2002, 2003; Fenster et al., 2003). The effects of using higher solids milk on the generation of fatty acids were determined. There were no significant differences in fatty acid levels in cheeses made with UF standardized or control milks (Table 7). Cheese making day had a significant $(P<0.05)$ effect on levels of caproic, caprylic, palmitic, and oleic acids. This probably reflects differences in the cheese making conditions used on different days, e.g., salting procedure. Informal sensory analysis by 3 experienced Parmesan graders did not reveal any obvious differences between the cheeses during ripening.

\section{CONCLUSIONS}

The use of cold UF retentates for the standardization of milks for Parmesan manufacture is an option for cheesemakers to consider, as there is a significant increase in cheese yield. In addition, there were only slight modifications (starter, rennet, adjuncts, and salt, which were added on a TS basis rather than volume of milk in the vat; the coagula from the UF standardized milks were cut sooner) necessary in the manufacturing protocol to make cheeses of the desired composition and quality. The large increase in yield is important in cheeses, such as Parmesan, which have been traditionally made from partly skimmed milk (i.e., milks with a low solids level and, therefore, low cheese yields). In addition, wheys derived from UF cheeses are reduced in volume but are more valuable as they contain more solids and the solids are richer in true protein. Milks with higher $\mathrm{CN}$ were cut sooner when rennet was added on a TS basis, and these gels had higher yield stress values, indicating greater re- 
Table 7. Mean squares, probabilities (in parenthesis), and $\mathrm{R}^{2}$ for the FFA formed during ripening of Parmesan cheese at $7^{\circ} \mathrm{C}$ for 10 mo.

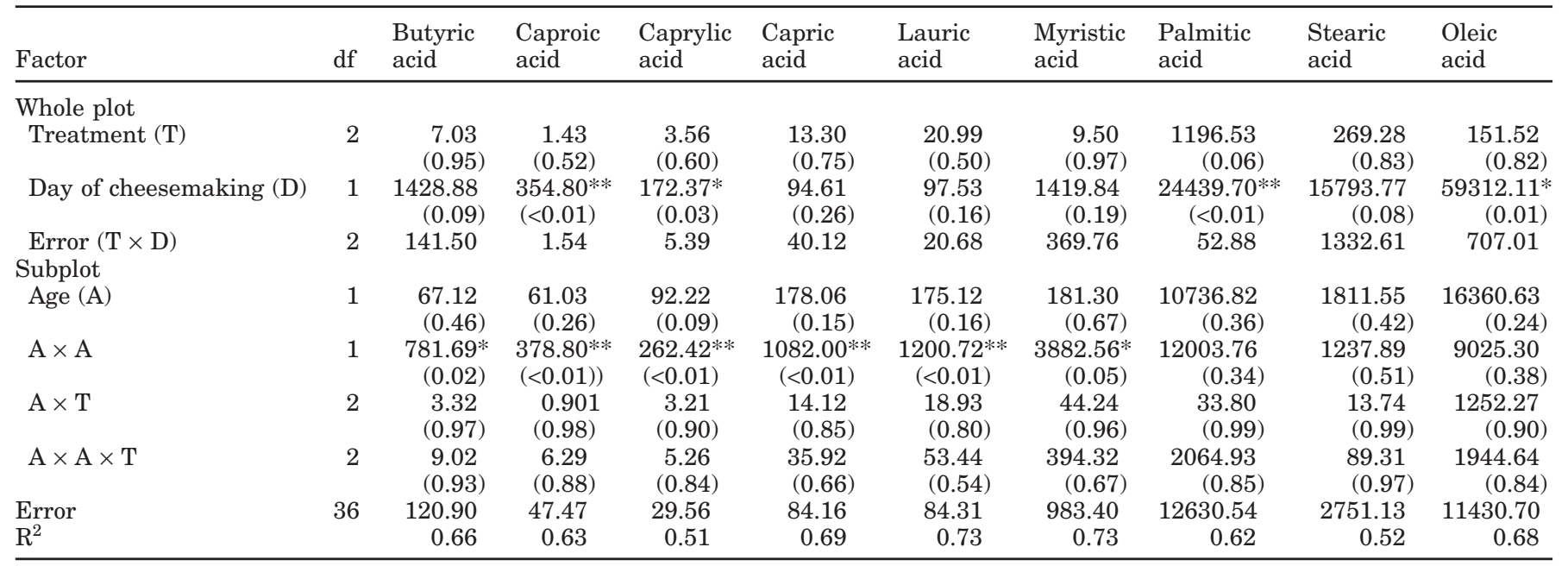

$* 0.01<P \leq 0.05$.

$* * P \leq 0.01$.

sistance to the cutting process. Proteolysis, the development of fatty acids during cheese ripening, and cheese quality were not affected by the use of milk high in $\mathrm{CN}$.

\section{ACKNOWLEDGMENTS}

The authors thank the Wisconsin Center for Dairy Research and University of Wisconsin dairy plant personnel for their assistance and support in membrane processing, milk processing, cheesemaking, and analytical work including Bill Hoesly, Bill Tricomi, Cindy Martinelli, Kristen Houck, Matt Zimbric, Juan Romero, Gene Barmore, Karen Smith, Ray Michaels, Ken Norton, Gina Mode, and Bill Klein. We also thank Robert Fassbender from T. C. Jacoby and Suresh Jambunathan, Dave Hibbard, and Derek Hibbard from Membrane Systems Specialists for all their assistance in setting up the UF units. We also thank Chr. Hansen, Inc. and Rhodia for their donation of starter cultures, adjuncts, and coagulants used in this study. The financial support of the Wisconsin Center for Dairy Research Cheese Industry Team, Wisconsin Milk Marketing Board, and Dairy Management Inc. is greatly appreciated.

\section{REFERENCES}

Anonymous. 1997. UV method for the determination of lactose and D-galactose in food stuffs and other materials. Boehringer Mannheim, RBiopharm, test kit catalog \# 10176303035.

Association of Official Analytical Chemists. 2000. Official Methods for Analysis. 17th ed. AOAC, Arlington, VA.

Banks, J. M., and D. D. Muir. 1985. Effect of incorporation of denatured whey protein on the yield and quality of Cheddar cheese. J. Soc. Dairy Technol. 38:27-32.
Bohlin, L., P. Hegg, and H. Ljusberg-Wahren. 1984. Viscoelastic properties of coagulating milk. J. Dairy Sci. 67:729-734.

Code of Federal Regulations. 2003. Food and Drugs: CFR 133.113$114,113.155-156$.

Creamer, L. K., M. Iyer, and J. Lelievre. 1987. Effect of various levels of rennet addition on characteristics of Cheddar cheese made from ultrafiltered milk. N. Z. J. Dairy Sci. Technol. 22:205-214.

Fassbender, R. 2001. Using cold ultrafiltered milk in cheesemaking. In Proc. of the Marschall Cheese seminar. Available: http:// www.marschall.com/marschall/proceed/index.htm 2001-3. Accessed Jan. 6, 2004.

Fenster, K. M., S. A. Rankin, and J. L. Steele. 2003. Accumulation of short $n$-chain ethyl esters by esterases of lactic acid bacteria under conditions simulating ripening Parmesan cheese. J. Dairy Sci. 86:2818-2825.

Green, M. L. 1985. Effect of pretreatment and making conditions on the properties of Cheddar cheese from milk concentrated by ultrafiltration. J. Dairy Res. 52:555-564.

Green, M. L., F. A. Glover, E. M. W. Scurlock, R. J. Marshall, and D. S. Hatfield. 1981. Effect of use of milk concentrated by ultrafiltration on the manufacture and ripening of Cheddar cheese. J. Dairy Res. 48:333-341.

Green, M. L., R. J. Marshall, and F. A. Glover. 1983. Influence of homogenization of concentrated milks on the structure and properties of rennet curds. J. Dairy Res. 50:341-348.

Green, W. C., and K. K. Park. 1980. Comparison of AOAC, microwave and vacuum oven methods for determining total solids in milk. J. Food Prot. 43:728-783.

Green, M. L., K. J. Scott, M. Anderson, M. C. A. Griffin, and F. A. Glover. 1984. Chemical characterization of milk concentrated by ultrafiltration. J. Dairy Res. 51:267-278.

Guinee, T. P., P. D. Pudja, and E. O. Mulholland. 1994. Effect of milk protein standardization, by ultrafiltration, on the manufacture, composition and maturation of Cheddar cheese. J. Dairy Res. 61:117-131.

Ha, J. K., and R. C. Lindsay. 1990. Method for the quantitative analysis of volatile free and total branched-chain fatty acids in cheese and milk fat. J. Dairy Sci. 73:1988-1999.

Jaeggi, J. J., S. Govindasamy-Lucey, Y. M. Berger, M. E. Johnson, B. C. McKusick, D. L. Thomas, and W. L. Wendorff. 2003. Hard ewe's milk cheese manufactured from milk of three different groups of somatic cell counts. J. Dairy Sci. 86:3082-3089. 
Johnson, M. E., C. M. Chen, and J. J. Jaeggi. 2001. Effect of rennet coagulation times on composition, yield, and quality of reducedfat cheddar cheese. J. Dairy Sci. 84:1027-1033.

Johnson, M. E., and N. F. Olson. 1985. A comparison of available methods for determining salt levels in cheese. J. Dairy Sci. 68:1020-1024.

Johnston, K. A., F. P. Dunlop, and M. F. Lawson. 1991. Effects of speed and duration of cutting in mechanized cheddar cheesemaking on curd particle size and yield. J. Dairy Res. 58:345-354.

Lawrence, R. C. 1989. The use of ultrafiltration technology in cheesemaking. Int. Dairy Fed. Bull. 240:2-15. IDF, Brussels, Belgium.

Lucey, J. A. 2002. Formation and physical properties of milk protein gels. J. Dairy Sci. 85:281-294.

Lucey, J. A., and J. Kelly. 1994. Cheese yield. J. Soc. Dairy Technol. 47:1-14.

Lucey, J. A., C. T. Teo, P. A. Munro, and H. Singh. 1997. Rheological properties at small (dynamic) and large (yield) deformations of acid gels made from heated milk. J. Dairy Res. 64:591-600.

Marshall, R. J. 1986. Increasing cheese yields by high heat treatment of milk. J. Dairy Res. 53:313-322.

Marshall, R. T., ed. 1992. Standard Methods for the Examination of Dairy Products. 16th ed. Am. Publ. Health Assoc., Inc. Washington, DC.

McMahon, D. J., B. H. Yousif, and M. Kalab. 1993. Effect of whey protein denaturation on structure of casein micelles and their rennetability after ultra-high temperature processing of milk with or without ultrafiltration. Int. Dairy J. 3:239-256.

O'Callaghan, D. J., C. P. O’Donnell, and F. A. Payne. 1999. Effect of protein content of milk on the storage and loss moduli in renneting milk gels. J. Food Process Eng. 22:249-261.
Qian, M., and G. Reineccius. 2002. Identification of aroma compounds in Parmigiano-Reggiano cheese by gas chromatography/ olfactometry. J. Dairy Sci. 85:1362-1369.

Qian, M., and G. Reineccius. 2003. Potent aroma compounds in Parmigiano Reggiano cheese studied using a dynamic headspace (purge-trap) method. Flavour Fragrance J. 18:252-259.

Raghunath, B., and D. C. Hibbard. 1997. Ultrafiltration of cooled milk. US Patent No. 5, 654, 025.

Reineccius, G. A. 2000. An overview of cheese flavour. Pages 12-30 in Proc. 6th Cheese Symp., Teagasc, Dublin, Ireland.

Shannon, E. L. 1969. Relationship of metabolism of Lactobacilli and pink discoloration of cheese. Ph.D. Thesis, University of Wisconsin-Madison, Madison.

Spangler, P. L., L. A. Jensen, C. H. Amundson, N. F. Olson, and C. G. Hill. 1990. Gouda cheese made from ultrafiltered milk: Effects of concentration factor, rennet concentration and coagulation temperature. J. Dairy Sci. 73:1420-1428.

Van Vliet, T., S. P. F. M. Roefs, P. Zoon, and P. Walstra. 1989 Rheological properties of casein gels. J. Dairy Res. 56:529-534.

Walstra, P., and R. Jenness. 1984. Pages 78-83 in Dairy Chemistry and Physics. John Wiley \& Sons, NY.

Wisconsin Department of Agriculture, Trade \& Consumer Protection. 2002. Pages 396-418 in Chapter ATCP 80.44 (2).

Woo, A. H., S. Kollodge, and R. C. Lindsay. 1984. Quantification of major free fatty acids in several cheese varieties. J. Dairy Sci. $67: 874-878$

Woo, A. H., and R. C. Lindsay. 1984. Concentrations of major free fatty acids and flavor development in Italian cheese varieties. J. Dairy Sci. 67:960-968.

Zoon, P., T. van Vliet, and P. Walstra. 1988. Rheological properties of rennet-induced skim milk gels. 1. Introduction. Neth. Milk Dairy J. 42:249-269. 